\title{
Lessons from COVID-19 in South Africa: Keeping our environment clean should be the first law of health
}

\begin{tabular}{|c|c|}
\hline \multicolumn{2}{|c|}{$\begin{array}{l}\text { Authors: } \\
\text { Sarentha Chetty } \\
\text { Varsha Bangalee }^{1,2}\end{array}$} \\
\hline \multicolumn{2}{|c|}{$\begin{array}{l}\text { Affiliations: } \\
\text { 'Department of Pharmacy } \\
\text { and Pharmacology, Faculty of } \\
\text { Health Sciences, University of } \\
\text { the Witwatersrand, } \\
\text { Johannesburg, South Africa }\end{array}$} \\
\hline \multicolumn{2}{|c|}{$\begin{array}{l}{ }^{2} \text { Department of Pharmacy, } \\
\text { Faculty of Health Sciences, } \\
\text { University of KwaZulu-Natal, } \\
\text { Durban, South Africa }\end{array}$} \\
\hline \multicolumn{2}{|c|}{$\begin{array}{l}{ }^{3} \text { Discipline of Pharmaceutical } \\
\text { Sciences, School of Health } \\
\text { Sciences, University of } \\
\text { KwaZulu-Natal, Durban, } \\
\text { South Africa }\end{array}$} \\
\hline \multicolumn{2}{|c|}{$\begin{array}{l}\text { Corresponding author: } \\
\text { Sarentha Chetty, } \\
\text { sarentha.chetty@wits.ac.za }\end{array}$} \\
\hline \multicolumn{2}{|c|}{$\begin{array}{l}\text { Dates: } \\
\text { Received: } 12 \text { Mar. } 2021 \\
\text { Accepted: } 30 \text { Apr. } 2021 \\
\text { Published: } 15 \text { June } 2021\end{array}$} \\
\hline \multicolumn{2}{|c|}{$\begin{array}{l}\text { How to cite this article: } \\
\text { Chetty S, Bangalee V. Lessons } \\
\text { from COVID-19 in South } \\
\text { Africa: Keeping our } \\
\text { environment clean should be } \\
\text { the first law of health. S Afr } \\
\text { Fam Pract. 2021;63(1), } \\
\text { a5297. https://doi. } \\
\text { org/10.4102/safp.v63i1.5297 }\end{array}$} \\
\hline \multicolumn{2}{|c|}{$\begin{array}{l}\text { Copyright: } \\
\text { C 2021. The Authors. } \\
\text { Licensee: AOSIS. This } \\
\text { is licensed under the } \\
\text { Creative Commons } \\
\text { Attribution License. }\end{array}$} \\
\hline \multicolumn{2}{|l|}{ Read online: } \\
\hline 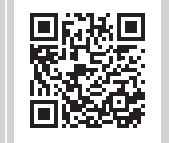 & $\begin{array}{l}\text { Scan this QR } \\
\text { code with your } \\
\text { smart phone or } \\
\text { mobile device } \\
\text { to read online. }\end{array}$ \\
\hline
\end{tabular}

In the wake of the coronavirus disease 2019 (COVID-19) pandemic, the links between poor hygiene, unclean environments and human health cannot be overemphasised, particularly in South Africa with its high incidence of infectious diseases and overburdened health system. One very controllable factor that is often overlooked is the poor disposal of litter and waste management and its adverse effects on public health. By wearing masks, regular handwashing and sanitising, as well as making sure that neighbourhoods and public spaces are clean and safe, the spread of COVID-19 and other diseases can be prevented.

Keywords: COVID-19; litter; hygiene; infection prevention; infectious disease.

\section{Introduction}

The link between poor hygiene and unclean environments on human health is not new. ${ }^{1,2}$ In 1989 , the European Charter on Environment and Health, stated that: 'Good health and well-being require a clean and harmonious environment in which physical, physiological, social and aesthetic factors are all given their due importance' (p. 2). ${ }^{3}$ Amongst the environmental contributors to poor health, the impact of litter and illegal dumping has far-reaching consequences. Litter is not only unsightly and odorous, but it can also adversely impact the environment, society and the economy. Regarding public health, it serves as a breeding ground for disease vectors including mosquitoes, flies, cockroaches, rats and parasites., ${ }^{4,5,6,7}$ The transmission of bacterial, viral and parasitic infections through solid waste contamination of the environment is well documented leading to a host of infectious and contagious diseases. ${ }^{5,6,7}$ Recently the link between unclean environments and disease transmission has been revisited in light of the novel Coronavirus disease 2019 (COVID-19). The rapid global spread of COVID-19 quickly catapulted the virus to pandemic status, making it a global health emergency. ${ }^{8,9}$

As the world cooperatively began to learn about the virus, research increasingly emerged, regarding not just the pathology but the molecular biology, transmission and lifespan of the virus. It was confirmed that COVID-19 is spread by the inhalation of infected droplets and contact with infected surfaces ${ }^{9}$ or possibly through aerosol spread. ${ }^{10}$ Furthermore, the virus could remain transmissible from objects including metal, glass, plastic and paper for an estimated period of up to 9 days. ${ }^{11}$ This was a game-changing discovery that served as a reminder of the effect of environmental hygiene on our health.

Maintaining a clean environment is particularly important in South Africa, where a large population of lower socio-economic individuals and families reside in densely populated informal settlements. ${ }^{12}$ The advent of COVID-19 and measures to try and contain the spread have brought to light the inadequate provision and inherent weaknesses in access to clean water, sanitation and waste removal in various communities across the country, ${ }_{1}^{13,14}$ which collectively reinforce the risk of disease transmission. ${ }^{14,15}$ For the greater part, these individuals are unable to reduce social contact as they do not have the luxury to work from their homes and they live in crowded spaces where lockdown regulations present a huge challenge. The notably lower levels of hygiene in these areas, owing to poor access to clean water, present a major obstacle to overcome the pandemic in South Africa. ${ }^{13,14,16}$ Despite these obstacles being beyond the control of those individuals living in informal settlements, and largely the mandate of the municipality, one controllable yet underemphasised factor for all South Africans especially in public spaces, is the responsible disposal of litter. This is a simple task that can save countless lives. In addition to this, it is imperative that government ensures that appropriate waste receptacles are accessible and that basic service delivery, that is, the timeous collection of rubbish and cleaning of streets and public spaces is conducted. 
As the country continues to loosen its lockdown restrictions, more South Africans are returning to work and venturing out into shared public spaces. As a precautionary measure, the mandatory use of face masks, as well as increased use of hand sanitisers and other protective equipment, have been advocated. Surgical masks are highly susceptible to being exposed to the virus because of respiratory droplets shed on them. These masks could also be infected with other pathogens, for example, meningitis or Hepatitis B. The majority of disposable masks are manufactured from plasticbased materials that are liquid-resistant and durable long after they have been discarded. ${ }^{17}$ Poor disposal of single-use masks, sanitisers and gloves, amongst other protective equipment, has resulted in a surge of medical wastes in the environment. ${ }^{17}$

This waste, together with other litter, has been finding its way to shorelines and landfills, where it is contaminating the soil and water and adding to an already polluted environment. The impact of this amount of waste is far-reaching and will affect plant, marine and animal ecosystems for years to come. ${ }^{17}$ The use of face masks is being advocated in a number of countries. Reports globally show that since the start of the COVID-19 pandemic there has been a huge upsurge in medical waste. ${ }^{18,19}$ Procedures for the safe disposal of medical waste within healthcare facilities have been suggested by the $\mathrm{WHO},{ }^{20}$ however a gap exists in domestic disposal and in disposal of contaminated waste outside healthcare facilities. Contagious waste could present an infection risk for other family members, waste collection workers and other members of the public. This could also present a risk of disease outbreaks. ${ }^{18,21}$ Several countries have recognised this risk and have adopted methods to mitigate the spread of the virus, which include special public bins and waste disposal procedures. ${ }^{18}$ This is something that South Africa should investigate and provide more public guidance.

To date, COVID-19 has claimed over 3116000 lives worldwide. ${ }^{22}$ In South Africa, a country that already has a high burden of infectious diseases, the largest number of HIV infections and the fourth largest TB population globally, this new public health crisis is bound to increase the strain on an already overburdened health system..$^{23,24}$ COVID-19 has directly and indirectly affected the functionality of the health system. In the early days of the pandemic, efforts to curb the spread of the virus resulted in reorganising the existing health workforce, as well as the suspension of certain services. Fear of contracting the disease also resulted in a reduced number of patients seeking medical attention. The overwhelming use of the health system by COVID-19 patients can compromise the ability of the health system to deliver other routine essential medical services. ${ }^{23,24}$ This could also increase morbidity and mortality from diseases other than COVID-19 and further increase the cost to the health system. ${ }^{23}$

Despite the appearance of promising vaccines, ${ }^{25}$ the focus in South Africa should still be on how to mitigate the spread of infection by improving access to clean water, good sanitation and increasing public awareness of pollution and littering and personal hygiene, as these strategies will continually impact the future health of the country. In the prevailing circumstances, the importance of infection prevention cannot be overstressed. We each have a role by being vigilant in the wearing of masks, regular handwashing and sanitising. By also making sure our neighbourhoods and public spaces are clean and safe, we can influence the spread of not just COVID-19 but other diseases too.

As the lockdown regulations ease and we venture back into our pre-COVID-19 existence, it is important that we heed the lessons of good hygiene in mitigating the spread of disease. The value of good personal hygiene and a clean environment should be imprinted in our memories. In the near future, governments should encourage discussion amongst public health experts, environmental scientists and epidemiologists to highlight the effect of an unclean environment on the health of the population. If we each do our part: the public by adhering to rules regarding responsible disposal of litter and the government by providing better service delivery, socio-economic development and investment and stronger enforcement of environmental regulations, we can ensure that common spaces are both aesthetically appealing and clean and safe. As the age-old advice goes 'Prevention is better than cure'.

\section{Acknowledgements Competing interests}

The authors declare that they have no financial or personal relationships that may have inappropriately influenced them in writing this article.

\section{Authors' contributions}

S.C. conceptualised and wrote the first draft. S.C. and V.B. both contributed to writing and editing of the manuscript.

\section{Ethical considerations}

Ethical approvals were not required for this article.

\section{Funding information}

The authors received no financial support for the research, authorship and/or publication of this article.

\section{Data availability}

Data sharing is not applicable to this article as no new data were created or analysed in this study.

\section{Disclaimer}

The views and opinions expressed in this article are those of the authors and do not necessarily reflect the official policy or position of an affiliated agency of the authors. 


\section{References}

1. Water, sanitation \& environmentally-related hygiene [homepage on the Internet] [Updated 2021 Feb 25; cited 2020 May 20]. Available from: https://www.cdc.gov/ healthywater/hygiene/index.html

2. Prüss-Ustün AWJ, Corvalán C, Bos R, Neira M. Preventing disease through healthy environments: A global assessment of the burden of disease from environmental risks [homepage on the Internet]. WHO; 2016 [cited 2020 May 20]. Available from: https://www.who.int/quantifying_ehimpacts/publications/preventing-disease/en/

3. European charter on environment and health [homepage on the Internet]. 1989 [cited 2020 Sept 20]. Available from: https://www.euro.who.int/_data/assets/ pdf_file/0019/114085/ICP_RUD_113.pdf

4. Quick facts on waste management, Litter [homepage on the Internet]. [cited 2020 Aug 30]. Available from: www.environment.gov.za

5. Sn C. Solid waste pollution: A hazard to environment. RAPSCI. 2017;2(3):555586 https://doi.org/10.19080/RAPSCI.2017.02.555586

6. Alam P, Ahmade K. Impact of solid waste on health and the environment. IJSDGE. 2013;2(1):165-168.

7. Nathanson JA. "Land pollution" [homepage on the Internet]. Encyclopedia Britannica; 2017. [cited 2021 Feb 28]. Available from: https://www.britannica. com/science/land-pollution

8. Chakraborty I, Maity P. COVID-19 outbreak: Migration, effects on society, global environment and prevention. Sci Total Environ. 2020;728:138882. https://doi. org/10.1016/j.scitotenv.2020.138882

9. Adhikari SP, Meng S, Wu YJ, et al. Epidemiology, causes, clinical manifestation and diagnosis, prevention and control of coronavirus disease (COVID-19) during the early outbreak period: A scoping review. Infect Dis Poverty. 2020;9(1):29. https:// doi.org/10.1186/s40249-020-00646-x

10. Coronavirus disease (COVID-19): How is it transmitted? [homepage on the Internet]. [updated $2020 \mathrm{Jul} 09$; cited 2020 Aug 20]. Available from: https://www. who.int/emergencies/diseases/novel-coronavirus-2019/question-and-answershub/q-a-detail/coronavirus-disease-covid-19-how-is-it-transmitted

11. Kampf G, Todt D, Pfaender S, Steinmann E. Persistence of coronaviruses on inanimate surfaces and their inactivation with biocidal agents. J Hosp Infect. 2020;104(3):246-251. https://doi.org/10.1016/j.jhin.2020.01.022

12. South Africa: Informal settlements status [homepage on the Internet]. [cited 2020 Oct 10]. Available from: http://www.thehda.co.za/uploads/files/HDA_Informal_ settlements_status_South_Africa.pdf
13. OPINION: Tackling COVID-19 in informal settlements in Cape Town [homepage on the Internet]. [updated 2020 Jul 08; cited 2020 Oct 20]. Available from: https:// news.trust.org/item/20200708104926-3gwm4/

14. Nyashanu M, Simbanegavi P, Gibson L. Exploring the impact of COVID-19 pandemic lockdown on informal settlements in Tshwane Gauteng Province, South Africa. Glob Public Health. 2020;15(10):1443-1453. https://doi.org/10.1080/174 41692.2020.1805787

15. Water and sanitation are obstacles in south Africa's COVID-19 fight [homepage on the Internet]. [updated 2020 May 05; cited 2020 Aug 25]. Available from: https:// www.circleofblue.org/2020/world/report-water-and-sanitation-are-obstacles-insouth-africas-covid-19-fight/

16. Van Belle S, Affun-Adegbulu C, Soors W, et al. COVID-19 and informal settlements: An urgent call to rethink urban governance. Int J Equity Health. 2020;19(1):81. https://doi.org/10.1186/s12939-020-01198-0

17. Saadat S, Rawtani D, Hussain CM. Environmental perspective of COVID-19. SC Total Environ. 2020;728:138870. https://doi.org/10.1016/j.scitotenv.2020.138870

18. Sangkham S. Face mask and medical waste disposal during the novel COVID-19 pandemic in Asia. CSCEE. 2020;2:100052. https://doi.org/10.1016/j.cscee.2020 100052

19. Peng J, Wu X, Wang R, Li C, Zhang $Q$, Wei D. Medical waste management practice during the 2019-2020 novel coronavirus pandemic: Experience in a general hospital. Am J Infect Control. 2020;48(8):918-921. https://doi.org/10.1016/j.ajic.2020.05.035

20. WHO. Laboratory biosafety guidance related to coronavirus disease 2019 (COVID-19) [homepage on the Internet]. [updated 2020 May 13; cited 2020 Nov 12]. Available from: https://apps.who.int/iris/bitstream/handle/10665/331138/ WHO-WPE-GIH-2020.1-eng.pdf

21. Mol MPG, Caldas S. Can the human coronavirus epidemic also spread through solid waste? Waste Manag Res. 2020;38(5):485-486. https://doi.org/10.1177/ $0734242 \times 20918312$

22. WHO coronavirus disease (COVID-19) dashboard [homepage on the Internet]. [cited 2020 Nov 16]. Available from: https://covid19.who.int/

23. Hofman K, Madhi S. The unanticipated costs of COVID-19 to South Africa's quadruple disease burden. S Afr Med J. 2020;110(8):698-699. https://doi. org/10.7196/SAMJ.2020.v110i8.15125

24. Nyasulu J, Pandya H. The effects of coronavirus disease 2019 pandemic on the South African health system: A call to maintain essential health services. Afr J Prim Health Care Fam Med. 2020;12(1):2480. https://doi.org/10.4102/phcfm.v12i1.2480

25. WHO. Draft landscape of COVID-19 candidate vaccines [homepage on the Internet]. [updated $2021 \mathrm{Feb} 26$; cited 2020 Nov 16]. Available from: https://www. who.int/publications/m/item/draft-landscape-of-covid-19-candidate-vaccines 